\title{
Water Supply from Turkey to Cyprus Island with Suspended Marine Pipeline
}

\author{
Izzet Ozturk \\ ozturk@itu.edu.tr \\ Istanbul Technical University (ITU), Istanbul, Turkey \\ Necati Agiralioglu \\ necati.agiralioglu@antalya.edu.tr \\ Antalya Bilim University, Antalya, Turkey \\ Omer Ozdemir \\ omeroz@dsi.gov.tr \\ General Directorate of State Hydraulic Works, Ankara, Turkey \\ Nasir Akinci \\ nakinci@kalyongrup.com \\ Kalyon Group, Turkey
}

\begin{abstract}
More than $90 \%$ of the water requirement for the Turkish Republic of Northern Cyprus (TRNC/KKTC) was being supplied from groundwater resources, while the rest was being provided from surface waters and seawater until the 1990s. Due to excessive water abstractions above their natural feeding levels, most of the aquifers had salinization as a result of sea water interference with electrical conductivity (EC) value exceeding $7000 \mathrm{mmho} / \mathrm{cm}$. In order to provide a permanent and long-term solution to the water problem in TRNC, a sea-crossing suspended water transmission pipeline (TRNC Water Supply) project has been developed for sustainable water transfer from Turkey to the Cyprus Island. While the initial feasibility and conceptual design studies have been prepared for State Hydraulic Works (DSI) in 1998-1999, the implementation projects and tender documents have been completed in 2006-2009, and the construction of the suspended marine pipeline has started in 2011 as commissioned by DSI. The engineering supervision and consultancy services of the project have been provided by a team from Istanbul Technical University (ITU). The project, which has been fully completed in October 2015 had a total cost of $1.6 \times 10^{9} \mathrm{TL}\left(600 \times 10^{6} \$\right)$, including expropriation costs. The unit cost of the water with flowrate $75 \times 106 \mathrm{~m}^{3} /$ year is calculated to be $0.6 \$ / \mathrm{m}^{3}$ $(n=15 \times 50$ years, $i=0.08)$, and the investment is expected to be repaid in 5.3 years. In this article, design details of the suspended marine pipeline and its critical components of this unique project are presented.
\end{abstract}

Keywords: Cyprus Island; TRNC; Water supply; Suspended marine pipeline; Innovative constructiontechnologies

\section{INTRODUCTION}

The TRNC had been experiencing an increasing water stress -in terms of both quantity and quality- for the last 30 years. Drinking and potable water requirements were met solely from the groundwater resources prior to completion of this project. Due to the excessive water extraction from aquifers, seawater intrusions had occurred in Mağusa, followed by Güzelyurt region, causing the salting of groundwater. The high quality 
groundwater obtained from Beşparmak Mountains served only a limited population. In the meantime, available dams and water ponds, alongside groundwater resources, had become insufficient with regards to significant population increase (Agiralioglu et al., 2018). In order to solve the major problem of water supply in the TRNC, a number of studies have been carried out including water transportation from Turkey to the island, however they could not be implemented at the time due to technological and/or financial difficulties (Agiralioglu, 2016). Finally, in 2011, the first step was taken towards the realization of Cyprus Water Supply Project, which was symbolically regarded as the Peace Water project.

As Cyprus is an island country having limited water resources, supplying water from Turkey to TRNC for human consumption, as well as for irrigation purposes, is expected to provide significant contribution to the development of the TRNC in general. Potable water need of the country will be met up to year 2045, and approximately 16000 ha of agricultural land will be irrigated. The climate of the region requires long and hot summers versus short and temperate winters alongside very fertile agricultural lands, thus, the provided water enables nearly 2-3 harvests in a year through irrigation.

This paper aims to review the main construction, economic and operation features of the TRNC Water Supply Project, putting forth certain comments that may be useful for the future of water resources management of the island.

\section{WATER SUPPLY PROJECT FROM TURKEY TO CYPRUS}

The implementation projects and tender documents of the water supply project from Turkey to Cyprus have been completed during 2006-2009 by Intech Engineering BV $\&$ Alarko Contracting Group (2008), and the construction of the suspended marine pipeline has started in year 2011 as commissioned by DSI. The engineering supervision and consultancy services relating to the sea-crossing component of the project has been provided by Istanbul Technical University (ITU, 2008).

The facilities built in the scope of project are gathered in three main groups, namely "Turkish Side Land Structures", "Sea Crossing Pipeline" and "TRNC Side Land Structures". These are;

Turkish Side Land Structures:

- $\quad$ Alaköprü Dam with 130.5 million $\mathrm{m}^{3}$ reservoir capacity and HEPP,

- $\quad 22.646 \mathrm{~km}$ long Turkish side transmission line with $1.500 \mathrm{~mm}$ nominal diameter,

- Anamur Balancing Chamber with $10.000 \mathrm{~m} 3$ capacity.

Sea Crossing Pipe Line:

- $\quad 80 \mathrm{~km}$ long HDPE pipeline with $1.600 \mathrm{~mm}$ nominal diameter.

TRNC Side Land Structures:

- Güzelyalı Pumping Station,

- $\quad 3.7 \mathrm{~km}$ long TRNC side force main with $1.400 \mathrm{~mm}$ nominal diameter,

- Geçitköy Dam with 26.5 million $\mathrm{m}^{3}$ reservoir capacity,

- Geçitköy Pump Station.

Turkish side land structures are located in the Anamur district in southern Türkiye and Sea crossing pipeline established in the Mediterranean Sea extending from Anamur to the Güzelyalı region located in west of Girne district of TRNC and the land structures of 
TRNC side also situated around the Geçitköy region. The general layout of the facilities built in the scope of this project is given in Figure 1 and the longitudinal section of the whole system is shown in Figure 2.

\subsection{Turkish Side Land Structures}

Alaköprü Dam. Alaköprü dam is the source of water transferred to the TRNC. It has been established on Dragon creek which has an annual water capacity of approximately 600 million cubic meters. The dam is concrete faced rock fill type with storage capacity of 130.5 million $\mathrm{m}^{3}$ and height of $94 \mathrm{~m}$ from thalweg of the creek. The image of the Alaköprü dam and the reservoir is shown in Figure 3.

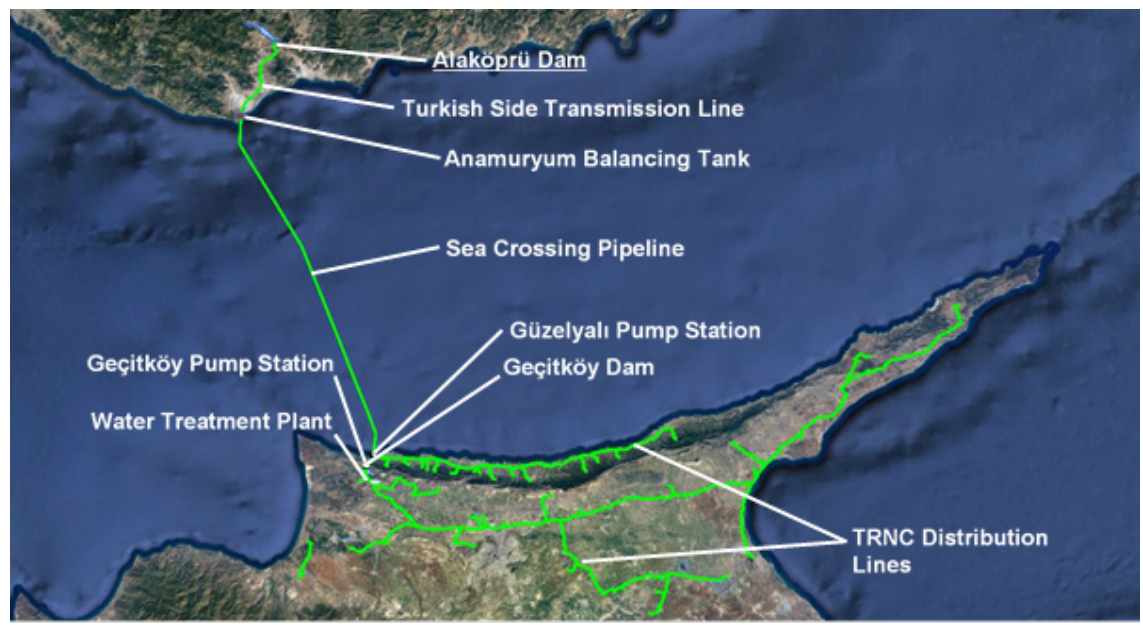

Figure 1: The General Layout of the Project

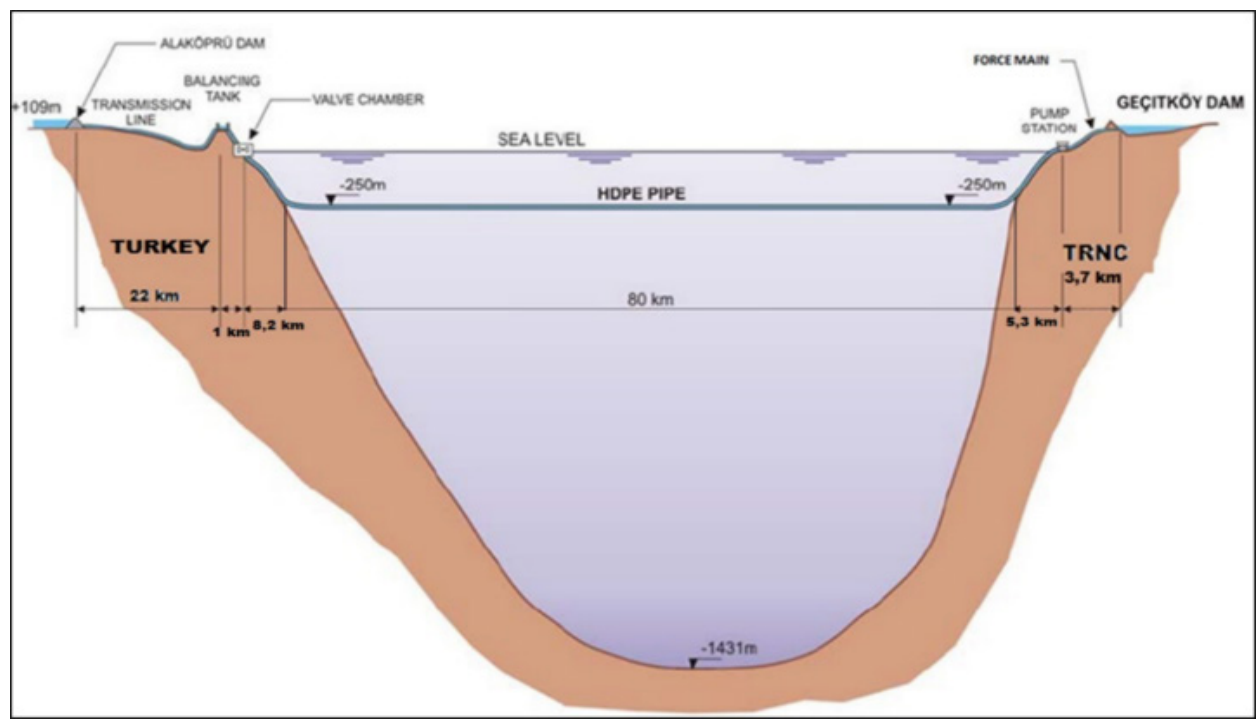

Figure 2: Longitudinal section of the whole system 


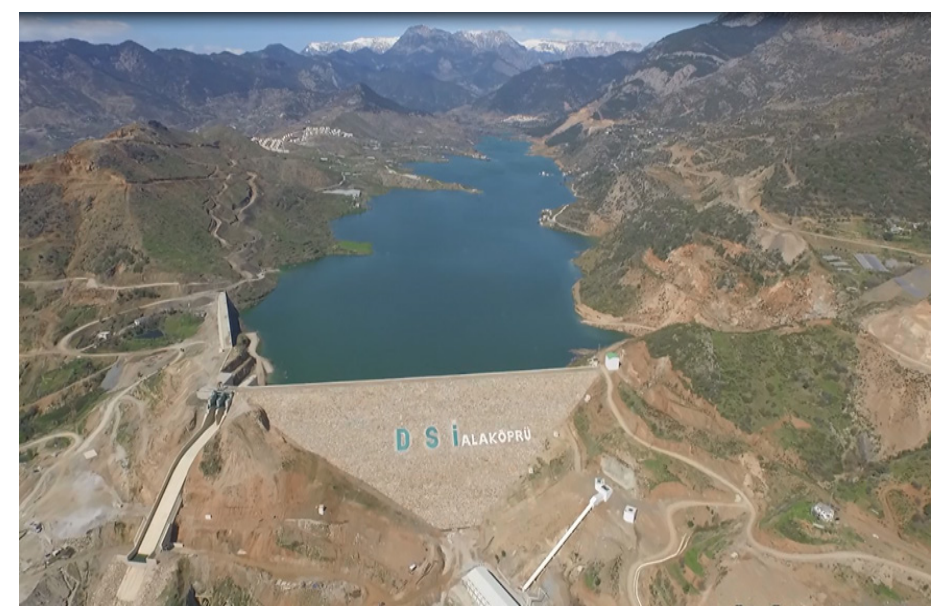

Figure 3: Alaköprü Dam and reservoir

Transmission pipeline. This pipeline is composed of ductile pipes with a diameter of $1,500 \mathrm{~mm}$ and a total length of $22.646 \mathrm{~km}$ which enables the water taken from the Alaköprü dam to be transferred first to the Anamur balancing tank and then to the sea crossing transmission line (see Figure 4).

Anamur balancing tank. Water taken from the Alaköprü Dam is delivered to this reservoir, which was built near the sea in Anamur. As the pressure of the water coming from the dam needs to be balanced due to the special hydraulic characteristics of the sea crossing pipeline, the name of the reservoir has the expression 'balancing'. The storage capacity of the tank is $10.000 \mathrm{~m}^{3}$.

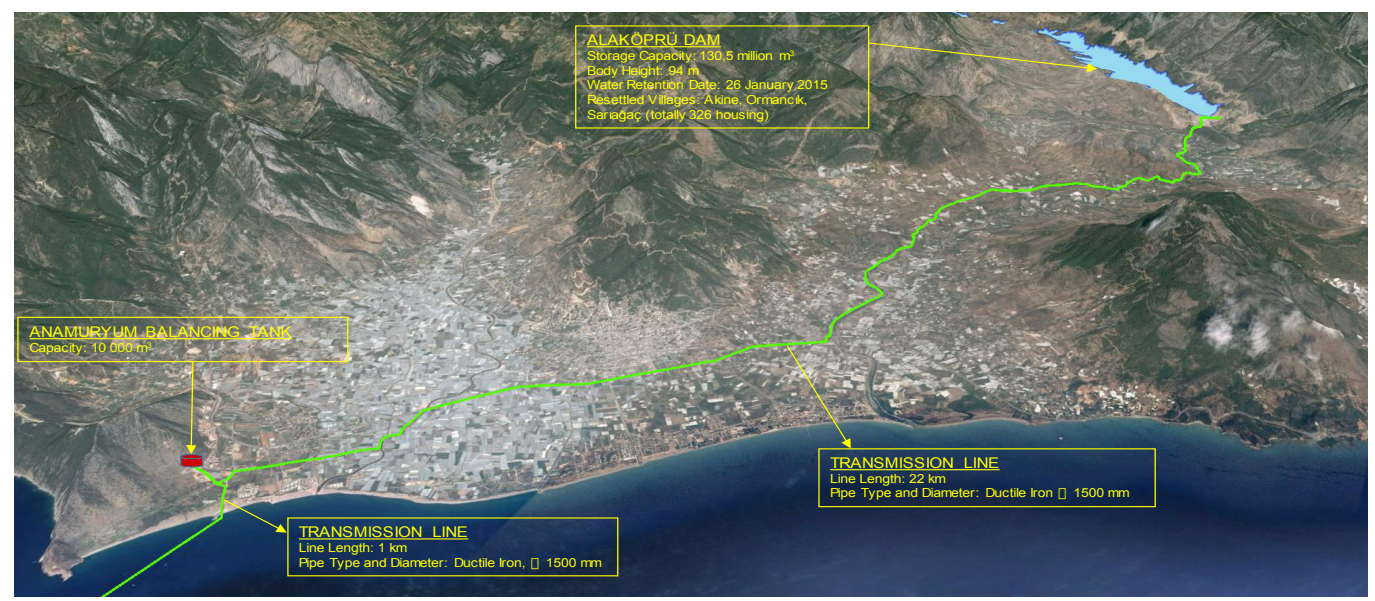

Figure 4: Pipeline and balancing tank

\subsection{TRNC Side Land Structures}

Güzelyalı Pumping Station. Water transmitted to the TRNC by gravity from Türkiye is pumped to the Geçitköy Dam by means of Güzelyalı Pumping Station situated on the route of sea crossing pipeline. The Pumping Station has 2 primary and 1 spare pumps 
with the total capacity of $2.38 \mathrm{~m}^{3} / \mathrm{h}$. The elevation height is $\mathrm{H}_{\mathrm{m}}=101.45 \mathrm{~m}$.

Force Main. The main has a length of $3.7 \mathrm{~km}$ and a nominal diameter of 1,400 $\mathrm{mm}$, which provides the transmission of water from the Güzelyal1 Pumping Station to Geçitköy Dam. Pipe type is mechanically connected ductile iron.

Geçitköy Dam. The water transferred from Turkey is stored in the reservoir of Geçitköy dam and is the source of water transferred to the TRNC. The dam is clay core rock fill type with storage capacity of 26.5 million $\mathrm{m}^{3}$ and height of $58 \mathrm{~m}$ from thalweg. The image of the Alaköprü dam and the reservoir is shown in Figure 5.

Geçitköy Pumping Station. The water stored in Geçitköy Dam is raised to a treatment plant with a capacity of $200.000 \mathrm{~m} 3$ / day through this pumping station. There are 5 original and 1 spare pumps at the Station with a capacity of $2.38 \mathrm{~m}^{3} / \mathrm{h}$. The elevation height is $\mathrm{H}_{\mathrm{m}}=233.61 \mathrm{~m}$.

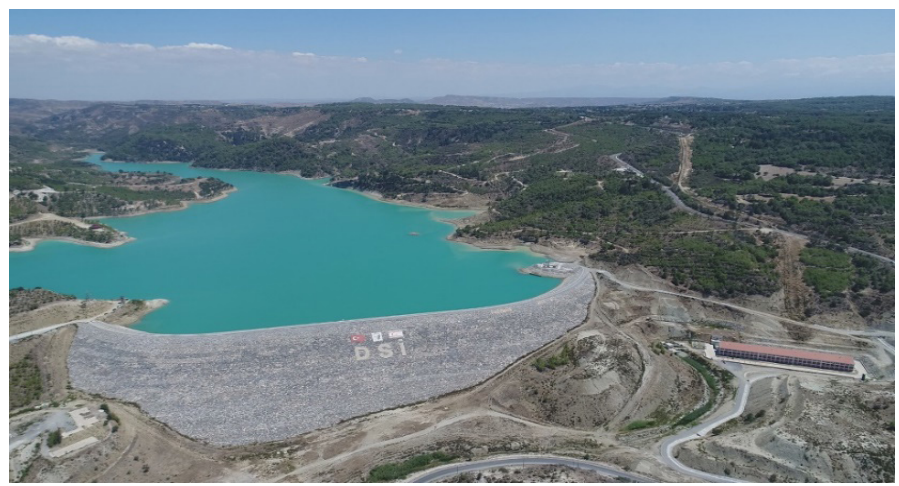

Figure 5: Geçitköy Dam and reservoir

\section{CRITICAL SYSTEM COMPONENTS OF SUSPENDED MARINE PIPELINE}

The Cyprus Water Supply (CWP) pipeline system will have a nominal capacity of $2.38 \mathrm{~m}^{3} / \mathrm{s}(75 \mathrm{mill} \mathrm{m} / \mathrm{yr})$ and will operate by gravity flow. The HDPE pipeline outer diameter is $1,600 \mathrm{~mm}$ with a PE100 material grade. The pipeline has an approximate true length of $80 \mathrm{~km}$. A wall thickness of $63 \mathrm{~mm}$ corresponding to SDR=26 is used along most of the route, with the exception of the Turkish on-bottom section where SDR=21 (corresponding to a wall thickness of $76 \mathrm{~mm}$ ). The battery limits (boundary conditions) for the offshore section of the CWP Pipeline System are shown in Figure 6.
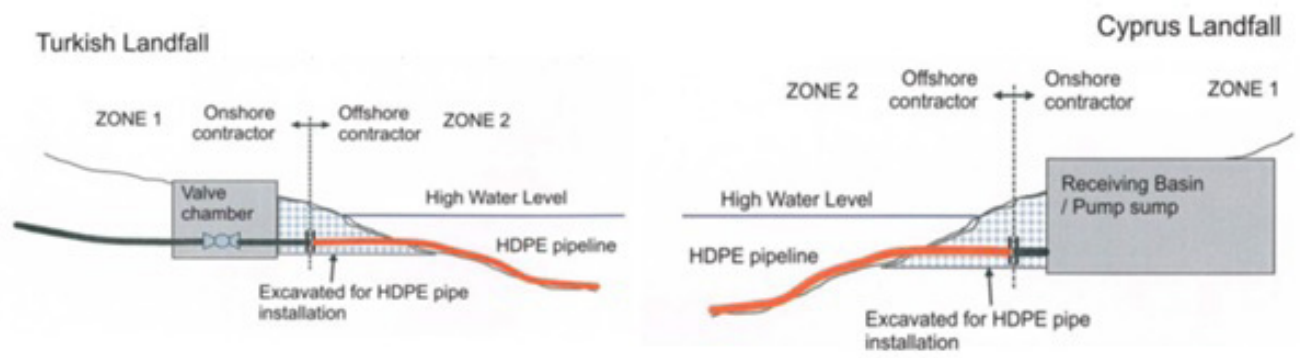

Figure 6: Battery Limit Definition -Turkey (a) Cyprus (b) 
On-Bottom Section Design. The on-bottom sections of the CWP pipeline system extend from the shore crossings up to a water depth of $280 \mathrm{~m}$ on both the Turkish and Cyprus sides. Figure 7 shows general layout of the on-bottom sections and names the main components.

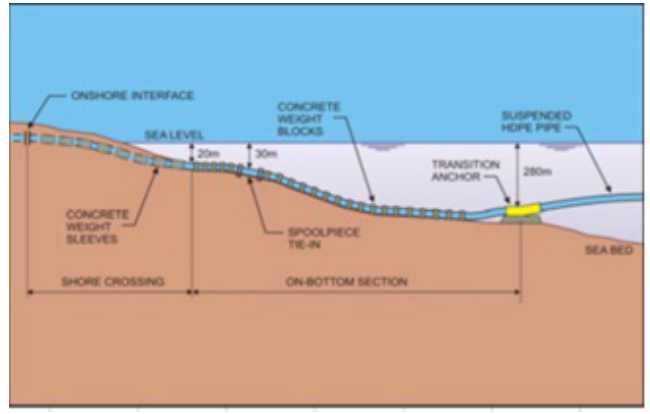

(a)

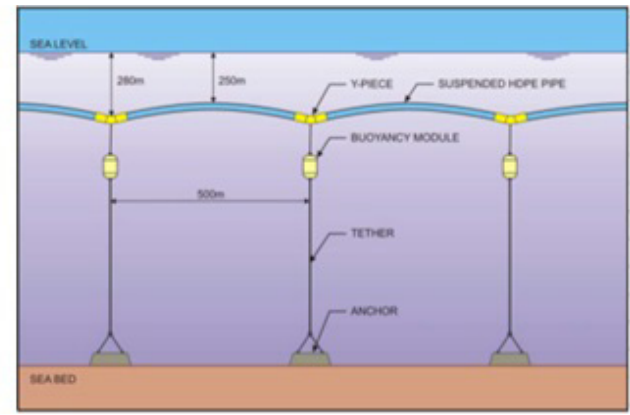

(b)

Figure 7: Schematic of On-Bottom Sections (a) Suspended Section General Arrangement (b)

Shore Crossing: In the shore crossing areas, the pipeline is to be installed in a precut trench. After pipeline installation into the trench, backfilling will be performed using suitable and approved materials either from the dredged materials or from materials imported from elsewhere. The Pipeline Shore Crossing Detailed Design Report prepared by Intec Eng. BV contains the following information: pipe deflection analysis, concrete weighting sleeve design, trenching and backfilling, liquefaction assessment.

Suspended Section Design: The suspended pipeline system extends from the $280 \mathrm{~m}$ water depth contour at the Turkish side to the $280 \mathrm{~m}$ water depth contour at the Cyprus Side. The main components of the suspended pipeline systems were shown in Figure 7.

System Configuration: Analysis has been performed during both the preliminary design and detailed design phases to define the overall suspended system configuration and to evaluate its behavior over a wide range of design conditions. It is noted that design reports address both the normal operating conditions of the pipe (including extreme environmental loading events) and several contingency / failure events. The failure events addressed include seabed instability resulting in anchor movement, tether failure above the buoyancy module, and tether failure below the buoyancy module. A basic principle of the suspended system design is that the pipeline shall be able to withstand all defined operating and environmental loads without failure. Furthermore, the system design shall be robust to withstand earthquake loads and accidental loads such as external impact.

The System Configuration and Dynamic Analysis Final Report prepared by Intec Eng. BV -recommended that confirmation of the fatigue properties of the material be performed. The fatigue resistance of the material is of critical importance due to the potential for vortex induced vibrations of the pipeline spans. A test program was initiated at Becetel Laboratories in Belgium during 2008 to assess both the fatigue and fracture properties of full-scale HDPE pipe wall samples (AES Engineering and Consultancy Ltd., 2014). 
Anchors: The Anchor Detailed Design Report presents detail design of the seabed anchors required to maintain the position of the suspended portion of the CWP pipeline. The basic function of each seabed anchor is the same; namely to react to the vertical and horizontal loads imposed by the buoy and suspended pipeline. The two anchors at the ends of the suspended configuration (called Transition Anchors) must also react to a significant horizontal load in addition to the vertical load. Four types of anchors have been designed: Type 1 is a basic gravity type anchor that reacts to the vertical load of the suspended system using its own self-weight. Type 2 is a gravity anchor with "skirts" along the bottom perimeter to penetrate into the seabed. The Type 3 anchor is an embedded drag anchor from a major anchor supplier. The final type of anchor, Type 4, is applied at the transitions from on-bottom to suspended configuration.

Tether System: The system configuration and Dynamic Analysis report defines the mooring requirements for the CWP suspended pipeline system. The Det Norske Veritas code for permanent offshore mooring systems has been used as the basis for the design. Requirements for corrosion allowance, minimum break loads, component details and minimum lengths are determined.

Buoyancy Module. The buoyancy modules will be made of syntactic foam material with an outer protective shell and an inner steel core for load transfer.

Y-piece. The Y-pieces will join the adjacent HDPE pipe spans to each other and to the buoy/tether/anchor system (Figure 8). This system must be robust to transfer the system loads during the entire design life, must interface with the adjacent components such as the buoy/tether/anchor system, and must allow for future diverless subsea intervention in the event of repairs. The Y-part that has been proposed as joining 3 pieces of stainless steel pipes in the preliminary design made by Intec Eng. BV, has indeed been manufactured without welding through the method of heat-bending (ITU, 2008 \& 2015) by the Salzfilter Mannesman Grobblech Incorporation in accordance to the American Bureau of Shipping's Guide for Building and Classing of Subsea Pipeline Systems ((ABS, 2006). In the HDPE pipe joints of the Y-part, stress/deformation analysis has also been performed with respect to the loading scenarios of both construction \& operation phases by the finite element method in order to show that the flanged connection is safe $\&$ sufficient (AES Ltd., 2014).

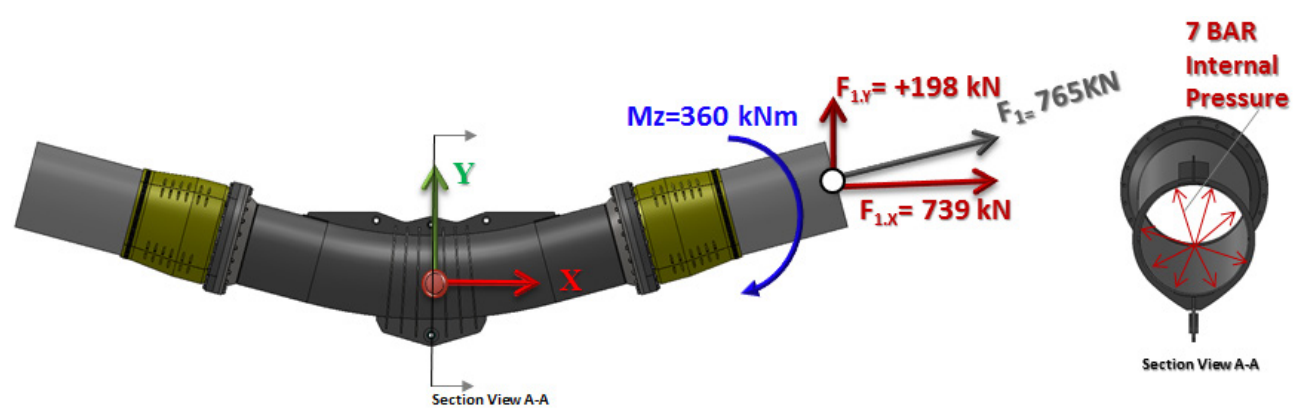

Figure 8: Operation Loads of the Turkey-side (TR \#1 Load Situation given as an example) 


\section{PROJECT COST}

The total cost (excluding expropriation costs) of the Cyprus Water Supply Project equals to $1,320 \times 10^{9} \mathrm{TL}\left(480 \times 10^{6} \$\right)$. The cost distribution of the project with respect to the facilities on both Turkey and Cyprus sides along with the suspended marine pipeline are given in Table 1.

Distribution of each project component in terms of construction works and equipment costs, along with account details of annual investment cost are also included in the same table. In the calculation of the annual investment cost, the interest and depreciation ratio is taken as $\mathrm{i}=0.08$, and the useful life value of the project is taken as $\mathrm{n}=50$ years (averagely) for construction components and $n=15$ years (averagely) for equipment \& installation.

Table 1. Cyprus Water Supply Project Cost Data (in 2015 Prices)

\begin{tabular}{|l|l|c|l|l|}
\hline Costs (x 10 & $\begin{array}{l}\text { Initial } \\
\text { Investment } \\
\text { Cost }\end{array}$ & $\begin{array}{l}\text { Construction Cost } \\
(n=50, i=0,08 \\
A / P=0,08174)\end{array}$ & $\begin{array}{l}\text { Equipment } \\
\text { Cost } \\
n=15, i=0,08 \\
A / P=0,11683\end{array}$ & $\begin{array}{l}\text { Annual } \\
\text { Investment } \\
\text { Cost }\end{array}$ \\
\hline Alaköprü Dam HEPP & 91 & 61 & 30 & 8.49 \\
\hline Buildings (Turkey) & 60 & 54 & 6 & 5.11 \\
\hline Sea Transition Line & 885 & 865 & 20 & 73.04 \\
\hline $\begin{array}{l}\text { Land Constructions (in } \\
\text { Cyprus) }\end{array}$ & 35 & 25 & 10 & 3.21 \\
\hline Geçitköy Dam & 29 & 23 & 6 & 2.58 \\
\hline Water Treatment Plant & 29 & 14 & 15 & 2.90 \\
\hline Water Distribution Line & 191 & 170 & 21 & 16.35 \\
\hline Total Costs & 1320 & 1212 & 108 & 111.69 \\
\hline
\end{tabular}

\section{Annual Investment Cost}

Annual investment cost of the project is calculated as $40.6 \times 10^{6} \$$ year with the abovegiven assumptions (Table 1).

\section{Operation and Maintenance Cost}

The annual operation and maintenance costs of the Cyprus Water Supply Project have been found as follows with two different approaches;

$\mathrm{OMC}_{1} \cong 0.03 \times$ Total Investment Cost $=14.4 \times 10^{6} \$ /$ year

$\mathrm{OMC}_{2} \cong 1 / 3 \times$ Annual Investment Cost $=40.6 / 3=13.5 \times 10^{6} \$ /$ year

\section{Total Annual Cost}

The total of annual investment and operation \& maintenance costs equals to; $(40.6+13.5) \times 10^{6} \cong 54 \times 10^{6} \$$ year

In this case, the gross unit cost of the project (per $\mathrm{m}^{3}$ water delivered) is $54 \times 10^{6} \$ /$ year $/ 75 \times 10^{6} \mathrm{~m}^{3} /$ year $=0.72 \$ / \mathrm{m}^{3}$. Considering the energy generation income at Alaköprü Dam, 26.5Í10 $10^{6} \mathrm{kWÍ180daysí24hÍl0.08 \$} / \mathrm{kWh}=9.161$ 10 $10^{6} \$$ year $\left(0.12 \$ / \mathrm{m}^{3}\right)$, the net unit cost of the project equals to $0.72-0.12=0.6 \$ / \mathrm{m}^{3}$.

With the assumption that $60 \%$ of the water delivered through Cyprus Water Supply Project will be used for drinking/municipal use and the remaining $40 \%$ for irrigation 
purposes, the total benefit to be obtained from the project can be calculated as $90 \times 10^{6}$ $\$ /$ year (Beaumont, 2000):

Revenue from sales of municipal water $\quad$ : 0.60 Í 75 Í1 $10^{6}$ Í $0.8 \$ / \mathrm{m}^{3}=36110^{6} \$ /$ year

Value added with irrigation in agriculture : 0.40 Í $75 \times 10^{6}$ Í $1.8 \$ / \mathrm{m}^{3}=54 \mathrm{I} 10^{6} \$$ year

In this case, the repayment period of the project investment can be taken as $480110^{6} / 90110^{6}$ $=5.3$ years. Therefore, Cyprus Water Supply Project provides a solution 33\% cheaper compared to water supply of sea water with RO (Reverse Osmosis) technology (0.9\$/ $\left.\mathrm{m}^{3}\right)$.

\section{WATER MANAGEMENT AND OPERATION STUDIES}

The Republic of Turkey (TR), and the Turkish Republic of North Cyprus (TRNC) have signed an agreement regarding the water management and operational studies within the scope of the TRNC Water Supply Project in March 2016, as the highlights of the agreement are given below:

The provided water from Turkey and local water of Cyprus are regarded as a whole in terms of management, planning, and allocation of water in the TRNC. The provided drinking-potable water is operated by a single operator in the TRNC. While the operation of the supplied water is carried out under the supervision of the TRNC, the agricultural areas to be irrigated with the provided water is decided upon with both the TR and the TRNC.

The enterprises responsible for both drinking-potable water, wastewater \& rainwater, and the agricultural irrigation are operated through separate tenders. Existing facilities and networks belonging to the public institutions \& municipalities in TRNC are delivered to the project operator upon contract. Investments that will be needed during the operation period specified for all drinking-potable water, wastewater \& rainwater, and agricultural irrigation facilities are made entirely by the operators.

The facilities on the Turkey side are managed by the General Directorate of State Hydraulic Works (DSI) with respect to operation, maintenance-repair, and all other technical issues. In addition to this, the DSI provides technical support in the facilities of the Cyprus side when required as well.

\section{CONCLUSION AND RECOMMENDATIONS}

Water supply from Turkey to Cyprus with the suspended marine pipeline remains to be the first and only project of its kind in this area. Since October $2015,75110^{6} \mathrm{~m}^{3} /$ year of water has been delivered to the TRNC, and the total construction cost equals to $480 I 10^{6} \$$, while the unit cost of water remains to be $0.60 \$ / \mathrm{m}^{3}$. It is clear with the project that an important step has been taken in terms of mitigating the effects of climate change (rainfall and river flow) which is becoming more apparent in the region on Cyprus side (Eastern Mediterranean). It is expected that there will be significant improvements in the quality of life of the residents with the efficient use of water delivered to the TRNC, especially in the municipal and agricultural sectors. In this context, loss/leakage (nonrevenue water) control in the water distribution networks, use of modern irrigation techniques, and reduction of evaporation losses in the Geçitköy Dam through floating solar energy panel system, along with the fact that these important facilities should be 
sustainably operated at full cost-based water tariffs are all considered to be important measures to be taken for the sustainability of water supply.

\section{ACKNOWLEDGMENTS}

First, we would like to thank Prof Veysel Eroğlu, the TR Minister of Forestry and Water Affairs of the time, for his great contributions in the realization of this unique project, and his bold vision. Due to the efforts and contributions in the project design, planning and construction phases, we are thankful to Alarko Contracting Group, Intec Engineering DV, Art1 Project, Danish Hydraulic Institute (DHI), AES Engineering Ltd, Firat Plastic Inc., and Kalyon - Sigur Ros Joint Venture, together with all stakeholders working on design and construction of the land structures of the project. We also extend our gratitude to the managers \& employees of the General Directorate of State Hydraulic Works (DSI) for their efforts in this project.

\section{REFERENCES}

ABS (2006). Guide for Building and Classing Subsea Pipeline Systems, s.25, Section 3.15.

AES Engineering and Consultancy Ltd. (2014). Cyprus Water Supply Project, Structural Analysis Report with HDPE and Steel Pipe Connections, Project Report. AES Engineering and Consultancy Ltd., Istanbul.

Agiralioglu, N. (2016). Cyprus Water Supply Project and Their Effects on Region, Project Report. Kalyon Construction, İstanbul.

Agiralioglu, N., Danandeh Mehr, A., Akdegirmen, Ö. \& Tas, E. (2018). Cyprus Water Supply Project: Features and Outcomes, 13th International Congress on Advances in Civil Engineering. 12-14 September 2018, Izmir/TURKEY.

Beaumont, P. (2000). The Quest for Water Efficiency - Restructuring of Water Use in the Middle East. Water, Air, and Soil Pollution, Vol: 123, 551-564.

Intech Engineering BV \& Alarko Contracting Group (2008). Cyprus Water Supply Project, Vol: $1-6$.

ITU (2008). Supervising and Consultancy (Scientific Support and Expert Inspection) Studies on Cyprus Water Supply Project, Alarko Contracting Group and General Directorate for State Hydraulic Works.

ITU (2015). The Assessment Report of Suspending Pipeline and Y-Piece at Cyprus Water Supply Project. 